\title{
How could you use the ergonomics 'know- how' transfer management to enhance human working for sustainable improvements in industrially developing countries?
}

\author{
Faramarz Helali ${ }^{*}$ \\ Department of Business Administration, Technology and Social Sciences, Department of Human Work Sciences, \\ Luleå University of Technology (LTU), Sweden
}

\begin{abstract}
This paper describes the different strategic understanding from getting ergonomics intervention programmes' conversations to 'Tip', including minimizing strategies; tipping point strategies; and maximizing strategies from building ergonomics intervention techniques. Those have indicated to different recognitions: 1) when amplification of the 'problem' is necessary; 2) when amplification of the 'tipping point' is necessary, and 3) when amplification of the 'success' is necessary. The practical applications and implications of the ergonomics intervention techniques are drawn from the findings of framing positive questions: 1) what is successful ergonomics intervention technique right now (Appreciative)? 2) What do we need to change for a better future (Imagine)? 3) How do we do this (Design)? 4) Who takes action and with what consequences (Act)? This requires re-framing of the ergonomics intervention techniques in an appreciative way, because of, the future action needs to be inspired by those things that participants feel are worth valuing, worth celebrating and sustaining.
\end{abstract}

Keywords: Ergonomics 'know-how' transfer management, Strategic understanding, Re-framing, Sustainable improvements, Industrial Developing Countries

\footnotetext{
*Corresponding author. Email: Faramarz.Faramarz@1tu.se
} 


\section{Introduction}

The workplace as a learning environment must be understood as a complex negotiation between knowledge-use, roles and processes - essentially as a question of the learner's participation in situated work activities [7]. On the other hand, Ghaye [10] asks 'In what ways can reflective practices enhance human flourishing?' However, Sanchez [6] gives us some direction when he proposes that three levels of understanding describe three levels of different kinds of knowledge within an organisation; know-how can be characterized as 'practical understanding' or learning by doing, know-why as 'theoretical understanding' or learning by studying, and knowwhat as 'strategic understanding' or learning by using. Recently, the author investigated and introduced models, associated methods, and outcomes from the systematic ergonomics 'knowhow' transfer management in an industrially developing country. This described an ergonomics 'know-how' as a proposed 'practical understanding' or ergonomics knowledge transfer management with different ergonomics intervention techniques (i.e. learning by doing individually and collectively as well as reflection-learning and action). Furthermore, put simply, the concept of action research that the author used in his study was one of 'learning by doing, individually and collectively'. One popular action research model is 'reflecting, planning, acting and observing'. There are many kinds of action research including: Action Research (AR), Participatory Action Research (PAR), and Participatory and Appreciative Action Research (PAAR) or reflection-learning and action [11-12]. Finding a way of distinguishing between AR, PAR and PAAR was the nature of the key questions that guided my research (see Helali's study [4]). Ghaye has mentioned 'R-Learning' (i.e., it is an intentional activity). This is learning that has four basic intentions. These have been described as learning to: develop appreciations; (re-) frame experience; build collective wisdom; achieve and move [9].

This paper describes the different 'strategic understanding' from getting ergonomics intervention programme conversations to 'Tip' as follows:

\section{Getting Ergonomics Intervention Programme Conversations to 'Tip'}

According to Helali's study [4] based on different evidence since 1996, in the opinion of the author, getting the ergonomics intervention programme conversations to 'tip' has opened up the following kinds of conversations: 1) recognizing when an amplification of the problem is necessary (including root cause of the 'problem', risk management, and critical reflective learning), and 2) recognizing when an amplification of the success is necessary (including appreciative reflective learning, appreciative inquiry, and root cause of success), see also, Ghaye, [9], (p. 167 and 168). Therefore, there are six different kinds of conversation that it has indicated can be used on the ergonomics intervention techniques with the different 'strategic understanding' or learning by using as follows:

\section{1 'Minimum Strategies': Recognizing when an amplification of the 'problem' is necessary (including, root cause of the 'problem' and risk management)}

There is a problem in focusing on problems because, deficit-phrased questions lead to deficitbased conversation [10]. For example, as a definition of a problem in industries of industrially developing countries like Iran, there are technical focus managers at work, a lack of interfaces between individual, group, and organizational levels at work, unsuitable work systems and unsuitable informal relationships within the organizations, and poor livelihood. However, when the author was an industrial manager prior to 1997 , he understood that business needs to move away from the narrow technical focus of getting the job done. The major resource for getting the job done is also people; and this implies that business managers need to take into consideration the well-being of their people, particularly as it relates to their continuing need for learning. This was one of the main reasons that the author's main focus at work was the learning strategy [4]. Furthermore, improving business effectiveness is brought by first improving the quality of experiential learning and participatory practices [7] as well as by reflective practices in society and within organizations [9]. Therefore, as the author's study [4], based on different case studies found, it is necessary to attend to improving organizational 
behaviour and suitable interfaces between individual, group, and organizational levels at work and also their livelihoods and 'building creative workplace culture'. The root cause is identified as a hierarchical style of management, poor action learning, poor workplace participatory learning, and poor productivity and livelihood in the industries of industrially developing countries such as Iran. The root cause eliminate can be: lack of or poor 'trust', (i.e. people do not trust others and feel they are not open and honest with them); lack of or poor 'team cohesion', (i.e. there is no sense of belonging and togetherness within a team or at work); lack of or poor 'communication', (i.e. workers do not understand what is expected of them and procedures and policies are not communicated); lack of or poor 'respect', (i.e. workers do not feel appreciated, valued or treated courteously by others); lack of or poor 'feeling supported', ( i.e. workers do not feel supported by management or that they can support one another).

Furthermore, the risk of establishing the ergonomics intervention programme could be when there are not commitment of people to learning at individual, group, and organizational levels. Sources of threats/risks were identified as the kind of improvement evaporation effect (lack of sustainability) which can occur following improvements in the competence and skill of workers if top managers or middle managers do not support the ergonomics intervention programme. The participants who took part in the ergonomics training workshop could not implement their learned knowledge to a greater extent at the local workplaces. Risk treatments (avoidance reduction, acceptance, and transfer) were implemented if we want to carry on ergonomics 'know-how' transfer through ergonomics training workshops. Then, we have to make incremental process improvement if we can do it at the organizational level. However, the organization works to minimize threats/risks and blame. Because of, Ghaye [10] describes 'the deficit trap, i.e. deficit-based questions $=$ deficit-based conversations $=$ spirals of deficit-based action as an interrelationship (p. 1072)'; in order to enhance human flourishing, we may have to shift reflective practices away from those that are concerned with 'problem', rather more, and towards practices that are more strengths-based.

\section{2 'Tipping point Strategies': Recognizing when an amplification of the 'Tipping point' is necessary}

\section{(including, Critical reflective learning and Appreciative reflective learning)}

Ghaye [9] explained 'tipping' when the goals, values and processes begin to be 'inhaled' by workers, the transformation process can spread, just like viruses do. The initiative becomes contagious. Workers are infected, with its spirit and purposes. Gradually and incrementally, year-on-year it takes a hold. It becomes addictive. One success leads to another until something exceptional happens (see also, Gladwell [5]). Practical knowledge is gained by reflecting on what works best and what works less well in a particular setting. Furthermore, reflective practices help us with four kinds of learning (i.e., cognitive, affective, action, and social learning), [9]. Therefore, in monitoring for critical reflective learning, a research questions which arose was: "What can we do together to make a positive difference here?" This meant an innovation of using ergonomics for improving work systems by the ergonomics intervention programme technique process [4]. However, 'space' has to be created to appreciate what is good and worthwhile in current practice. On the other hand, four types of energies are exemplified by Ghaye [8-9] as standing to provide a 'frame' for understanding the workplace transformation processes: (i) Emotional energy, which relates to how employees feel about taking on the challenges associated with particular workplace transformation; (ii) Physical energy, which relates to how much physical energy employees have to devote to the process of transformation, given that workers are often juggling numerous commitments; (iii) Mental energy, which relates to how far employees can find the mental energy to stay focused, for long enough, on the transformation process without distraction from other commitments, and (iv) spiritual energy, which relates to how far employees' own values are aligned with those advocating the transformation, as value alignment is a source of enduring motivation.

\section{3 'Maximum Strategies': Recognizing when an amplification of the 'success' is necessary (including, Appreciative inquiry and Root cause of success)}

According to Ghaye [9] power of asking appreciative questions is a key part of Participatory and Appreciative Action Research (PAAR) and, for some, a useful starting strategy. In an appreciative 
way, what might be 'Appreciative Intervention Work Process? (See Figure 1)

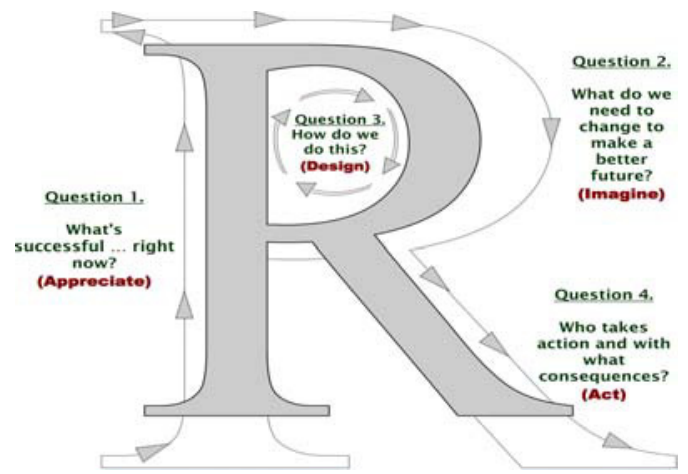

Figure 1. Using the power of the positive question to enhance human flourishing (source; Ghaye, [10]) or what might be ‘Appreciative Intervention Work' Process?

Because of, Appreciative Inquiry is the study and exploration of what gives life to human systems when they are at their best (see, Whitney and Trosten-Bloom, [3]). These questions are carefully phrased in order to grab our attention, because our motivation to explore them supersedes whatever is going on at work right now [10]. On the other hand, according to, Thatchenkey and Metzker [13] Appreciative Intelligence is the ability to perceive the positive inherent generative potential within the present.

\section{Discussion and Conclusion}

The practical applications and implications of the ergonomics intervention techniques (see also, Helali' study [4]) are drawn from the findings of the framing positive questions. There is an ability to engage in appreciative reflection and appreciative action them now. Because of, the appreciative reflection is a new form of reflection and it requires four basic types of appreciative intent toward, knowing, relating, action, and organizing [9-10].

\subsection{What is the successful ergonomics intervention technique right now (Appreciative)}

Appreciative inquiry and appreciative intelligence are considering something that is looking towards a better future, not necessarily what is wrong. Thatchenkey and Metzker [13] noted that appreciative intelligence is not about denying that part of reality exists. It is about the ability to re-frame it for a better view of the future. As a 'Meta-
Reflection' (i.e., this is thinking again about reflection-on-practice), the author has learned some new words on the action pathway of the ergonomics intervention programme journey (Table 1) and see also, Helali's study, [4].

Table 1

Lessons learned from some new words of the action pathway ergonomics intervention programme journey

\begin{tabular}{|c|c|c|}
\hline Old Words & New Words & $\begin{array}{l}\text { Positive Challenges, } \\
\text { appreciative way }\end{array}$ \\
\hline Inquiry & $\begin{array}{l}\text { Appreciative } \\
\text { Inquiry, Whitney } \\
\text { and Trosten- } \\
\text { Bloom, [3] }\end{array}$ & $\begin{array}{l}\text { "What might be the } \\
\text { 'appreciative core } \\
\text { positive question' for } \\
\text { amplifying?" }\end{array}$ \\
\hline Intelligent or IQ & $\begin{array}{l}\text { Appreciative } \\
\text { Intelligence (AI): } \\
\text { Thatchenkey and } \\
\text { Metzker, [13] }\end{array}$ & $\begin{array}{l}\text { "What is it we want } \\
\text { more of here?" There } \\
\text { are three components } \\
\text { of AI (i.e., 're- } \\
\text { framing, appreciating } \\
\text { the positive, and } \\
\text { seeing how the future } \\
\text { unfolds from the } \\
\text { present') Whitney and } \\
\text { Trosten-Bloom, [3] }\end{array}$ \\
\hline Conversation & $\begin{array}{l}\text { Appreciative } \\
\text { Conversation }\end{array}$ & $\begin{array}{l}\text { What might it be that } \\
\text { we want more of } \\
\text { here? }\end{array}$ \\
\hline Intervention work & $\begin{array}{l}\text { Appreciative } \\
\text { Intervention Work }\end{array}$ & $\begin{array}{l}\text { What might be a way } \\
\text { to work ethically with } \\
\text { people at workplaces? }\end{array}$ \\
\hline $\begin{array}{l}\text { Ergonomics } \\
\text { Intervention } \\
\text { Programme (EIP) }\end{array}$ & Appreciative EIP & $\begin{array}{l}\text { What might be the } \\
\text { ergonomics } \\
\text { intervention technique } \\
\text { (EIT) we want more } \\
\text { of here, and how can } \\
\text { we amplify this in } \\
\text { appreciative ways? }\end{array}$ \\
\hline Innovating & $\begin{array}{l}\text { Appreciative } \\
\text { Innovating }\end{array}$ & $\begin{array}{l}\text { What will it be we } \\
\text { want more of here? }\end{array}$ \\
\hline $\begin{array}{l}\text { Learning/Action } \\
\text { Learning Or } \\
\text { Action Research } \\
\text { and Participatory } \\
\text { Action Research }\end{array}$ & $\begin{array}{l}\text { 'Reflective } \\
\text { Learning and } \\
\text { Action' Or } \\
\text { Participatory and } \\
\text { Appreciative } \\
\text { Action Research } \\
\text { (PAAR), Ghaye, } \\
\text { [11-12] }\end{array}$ & $\begin{array}{l}\text { "What is it we want } \\
\text { more of here, and } \\
\text { how can we amplify } \\
\text { this?" Also, "How } \\
\text { does the future unfold } \\
\text { from an appreciation } \\
\text { of the positive } \\
\text { present?" }\end{array}$ \\
\hline Leading & $\begin{array}{l}\text { Leading through } \\
\text { appreciative } \\
\text { Ghaye, [9] }\end{array}$ & $\begin{array}{l}\text { Look at present } \\
\text { values; "How will we } \\
\text { go further here?" }\end{array}$ \\
\hline
\end{tabular}

They might be significant for the searching and understanding (research) appreciative intervention work now.

\subsection{What do we need to change to make a better} future? (Imagine) 
Based on the Work System Sub-Systems (Kleiner, [1]) study, what can be a conceptual model of an Appreciative Work System'? This can be seen in Figure 2. This is also indicated the key characteristics of the socio-technical system components identified (see, Kleiner, [1]). However, this might be necessary for "working better together" in an appreciative way that practitioners who undertake the appreciative work system or the ergonomics 'know-how' transfer entrepreneurial management begin 'journeying along action pathways-to-scale' with usefulness factors; i) values (i.e., developing an understanding and

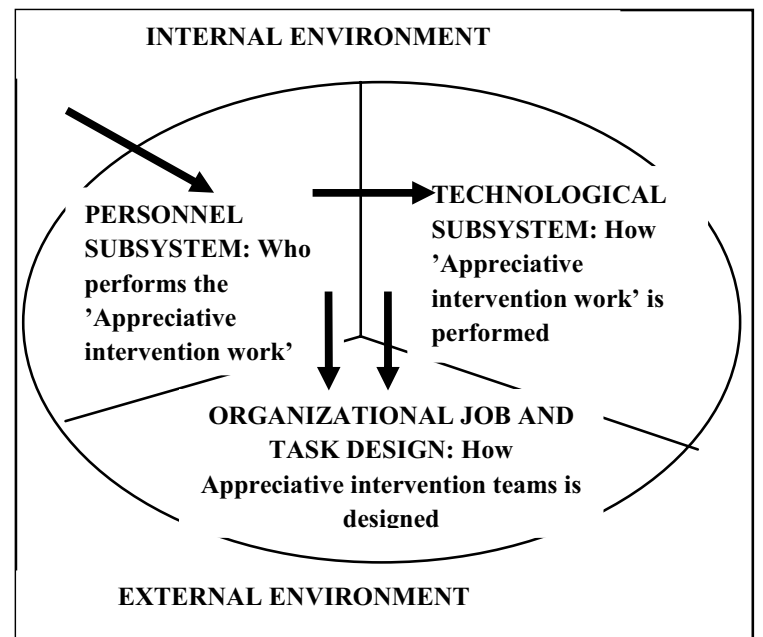

Figure 2. Basic conceptual model of an 'Appreciative Work System', (adapted resource: Kleiner, [1], p.70)

congruence between espoused and values-in-action), ii) conversation (i.e., using the power of the positive question), iii) user (i.e., here; learning from end-users and participants' experiences), iv) leadership (i.e., leaders using their appreciative intelligence), v) team (i.e., learning shared within and between teams), vi) network (i.e., linked groups working in a knowledgesharing way) or 're-framing' ergonomics intervention techniques to purpose how can 'appreciation' becomes an organization-wide work habit? (See also, Ghaye, [9], p. 214-215) This might be about caring about growth-promoting and improvement-enhancing relationships for an appreciative work system in industries of industrially developing countries.

\subsection{How do we do this? (Design)}

The 'developing insight though action' might be a main point of the starting for an 'appreciative intervention work' project in the workplaces with focus on the following sub-research questions that it can be formulated: "What are your workplace "stories", " journeys", "culture" and "ballets (i.e. dances)" about the applying ergonomics since and how you want amplify it?

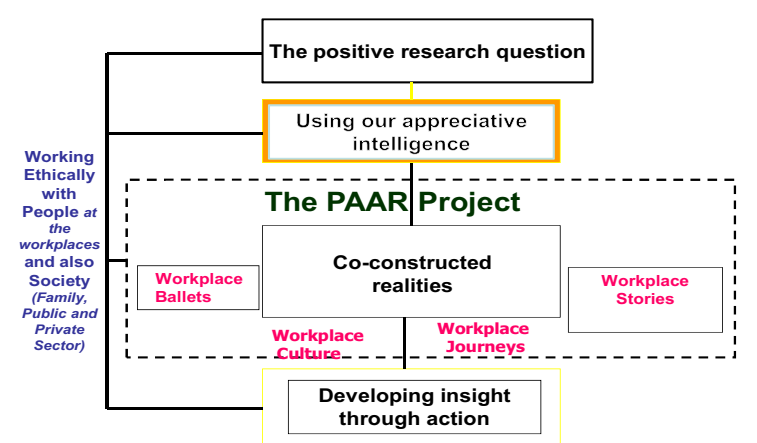

Figure 3. The PAAR Project, source; Professor Tony Ghaye, PAAR discourse, 2008, LTU-Sweden

In totality, this is mentioned that PAAR is about: 1) using the power of the positive question, 2) amplifying the core positive question not 'problem solving'; 3) leading by valuing, not evaluating; 4) 'Appreciative Intelligence' (multiple intelligence); the ability to see the mighty oak in the acorn, and look at all successful things; 5) 're-framing' (i.e., how one can amplify those things that will help a better future emerge from positive present) by choice not one and best way for doing, or seeing how the future unfolds from the present (see, Ghaye [11]).

\subsection{Who takes action and with what consequences? (Act)}

Ghaye [10] states the organizing for the best individual, group, organization and community practices from an appreciative stance. The role of researchers is research (understanding) with company and participation of people, not on people or techniques and tools, etc. The role of people are to engage in the appreciate path to ask and reply to the reflective questions and also what can they learn from each other and service end-users' experience? Ghaye, et al, [12] describe four strategic 'turns' (i.e., a change in direction from one way of thinking, practising, and using it to another). This requires reframing of the ergonomics intervention techniques in an appreciative way, because of, the future action needs to be inspired by those things that participants feel are worth valuing, worth celebrating and sustaining. 


\section{References}

[1] B. M. Kleiner, Macroergonomics: Work System Analysis and Design, HUMAN FACTORS, Vol. 50, No. 3, 2008, pp. 461467.

[2] C. Kim and R. Mauborgne, Tipping point leadership. Harward Business Review, April, 2003, 60-69.

[3] D. Whitney and A. Trosten-Bloom, The Power of Appreciative Inquiry: A Practical Guide to Positive Change; Berrett-Koehiler Publishers, Inc. San Francisco, 2003.

[4] F. Helali, Developing an ergonomics intervention technique model to support the participatory ergonomics process for improving work systems in organizations in an industrially developing country and its "Meta-Reflection". [Doctoral dissertation]. Luleå, Sweden: Luleå University of Technology, 2008; PDF retrieved April 30, 2011, from: http://epubl.1tu.se/1402-1544/2008/28/LTU-DT-0828-SE.pdf

[5] M. Gladwell, The Tipping Point: How little things can make a big different, Abacus, London. 2000.

[6] R. Sanchez, Strategic Product Creation: Managing New Interactions of Technology, Markets and Organizations. European Management Journal, 1996, 14:2, 121-138.

[7] S. Billett, Workplace participatory practices Conceptualizing workplaces as learning Environments. The Journal of Workplace Learning Vol.16. 6, 2004, 312-324.

[8] T. Ghaye, Developing the reflective healthcare team. Oxford, UK. Blackwell. 2005.
[9] T. Ghaye, BUILDING THE Reflective Healthcare Organization. Blackwell Publishing. 2007.

[10] T. Ghaye, Editorial: In what ways can reflective practices enhance human flourishing? Reflective Practice, Vol. 11. No. 1, 2010, pp. 1-7.

[11] T. Ghaye, Participatory and Appreciative Action Research (PAAR) Some Principles and Processes (an extract from Ghaye, T (2008), An introduction to Participatory and Appreciative Action Research (PAAR), New Vista Publications, Gloucester, England. 2008.

[12] T. Ghaye, A. Melander-Wikman, M. Kisare, P. Chambers, U. Bergmark, C. Kostenius, and S. Lillyman, Participatory and appreciative action and research (PAAR) - democratizing reflective practices. Reflective Practice, Vol. 9, No. 4, November 2008, 361-397.

[13] T. Thatchenkery and C. Metzker, Appreciative Intelligence: Seeing the Mighty Oak in the Acorn. Berrett-Koehler, San Francisco, CA. 2006. 